\title{
Investing Dirty Money: Section 1962(a) of the Organized Crime Control Act of 1970
}

In response to its perception of "organized crime"1 as a major threat to American society, ${ }^{2}$ Congress passed the Organized Crime Control Act of 1970 (OCCA-70). ${ }^{3}$ The purpose of OCCA-70 was to eradicate organized crime by strengthening the legal tools in the evidence-gathering process ${ }^{4}$ and by establishing new penal prohibitions with particularly severe sanctions.5 New procedural tools devised to facilitate the gathering of evidence comprise seven ${ }^{6}$ of the

1. "Organized crime" is the term used to describe the various groups of people who have made it their business to supply illegal goods and services. The major "service" supplied is the opportunity to gamble. Organized crime is also involved in the importation and distribution of drugs, prostitution and loan sharking. These illegal businesses are apparently very profitable; the President's Commission on Law Enforcement and the Administration of Justice estimated that organized crime grosses from seven to fifty billion dollars each year. See U.S. PRESIDENT'S COMM'N ON LAW ENForcement and the Administration of Justice, TASK Force on Organized Crime: Report 4 (1967) [hereinafter cited as Task Force on Organized Crime].

No one has ever authoritatively determined whether a monolithic criminal organization, known as the Mafia and composed of a number of "families" actually exists. Some writers argue that the "Mafia" is no more than discrete groups of people engaged in similar kinds of criminal activity. D. BELL. THE END OF IDEOLOGY (1959); D. Cressey, The Theft of the Nation (1969); C. Mollenhoff, Strike Force (1972); N. Morris \& G. Hawkins, The Honest Politician's Guide to Crime Control (1970); G. Tyler, Organized Crime in America (1962); Johnson, Organized Crime: Challenge to the American Legal System I, 1963 J. CRIM. L.C. \& P.S. 399; Woetzel, An Overview of Organized Crime: Mores versus Morality, 47 AnNaLs 1 (1963).

2. See, e.g., Schelling, Economic Analysis and Organized Crime, in TASK FoncE oN ORGANIzEd CrIME 114; Schelling, What is the Business of Organized Crime?, $20 \mathrm{~J}$. PuB. L. 71 (1971); sources cited in note 4 infra.

3. Pub. L. No. 91-452, 84 Stat. 922. The sections of the Act are codified in scattered sections of the United States Code. See notes 6-10 infra.

4. The President's Commission on Law Enforcement and the Administration of Justice identified a number of reasons why organized crime continues to grow despite efforts to arrest and reverse its development. It noted the lack of law enforcement resources, the lack of coordination by federal and state officials, and the lack of public and political commitment to finding a solution to the problem of organized crime. See U.S. PRESIDENT's CoMm'N ON LAw ENForcement and THE AdMinistration of Justice, Report: The Challenge of Crime in a Free Society 198-200 (1967) [hereinafter cited as Challenge of Crime]; TASk force on Organized Crime, supra note 1, at 1 .

The most serious legal obstacle to effective control of organized crime is the difficulty of obtaining evidence. See Challenge of Crime, at 196, 198-200; Senate Comm. on the Judiciary, Report on Organized Crime Control Act of 1969, S. Rep. No. 617, 9lst Cong., 1st Sess. 44-45 (1969) [hereinafter cited as SENATE REPORT]; Hearings on Measures Relating to Organized Crime Before the Subcomm. on Criminal Laws and Procedures of the Senate Comm. on the Judiciary, 91st Cong., Ist Sess. 112-13, 176-78, 499-502 (1969) [hereinafter cited as Senate Hearings]; Hearings on Controlling Crime Through More Effective Law Enforcement Before the Subcomm. on Criminal Laws and Procedures of the Senate Comm. on the Judiciary, 90th Cong., 1st Sess. 913, 940, 957-58 (1967).

5. See Pub. L. No. 91-452, § 1, 84 Stat. 922.

6. Title I of OCCA-70, 18 U.S.C. $\$ \$ 3331-39$ (1970) authorizes special grand juries to investigate organized crime. Title II, 18 U.S.C. $\$ \S 6001-05$ (1970), collects and reforms testimonial immunity provisions previously scattered throughout the Code. See 
thirteen sections of the Act. Of the remaining six substantive sections, only three deal specifically with organized crime-as opposed to crime in general. ${ }^{7}$ One of these sections increases sentences for "dangerous offenders"; 8 another outlaws conducting a gambling business. ${ }^{9}$

The last substantive section of the Act dealing specifically with organized crime, Title IX, ${ }^{10}$ is an attempt to halt organized crime's incursion into legitimate business. ${ }^{11}$ Section $1962^{12}$ defines three new

SENATE ReroRT, supra note 4, at 5-11, $51-56,104-48,172-94$. Title III, 28 U.S.C. \$ 1826 (1970), provides penalties to be imposed for refusal to testify after a grant of immunity. Title IV, 18 U.S.C. $\$ 1623(1970)$, deals with perjury. Title V, 84 Stat. 933, authorizes security measures to protect witnesses. It was not assigned a place in the United States Code; it defines cextain powers Congress has now awarded to the Attorney General. Title VI, 18 U.S.C. $\$ 3503(1970)$, outlines deposition procedures. Title VII, 18 U.S.C. $\$ 3504$ (1970) attempts to limit the applicability of the "exclusionary rule." See Mapp v. Ohio, 367 U.S. 643 (1961).

7. One of the remaining three is the separability section. Title XIII-General Provisions, 84 Stat. 922. The other two sections are: (1) Title XI-Regulation of Explosives, 18 U.S.C. \$\$ $841-48 \quad(1970)$ and (2) Title VII-National Commission on In. dividual Rights, 84 Stat. 935, 1970 U.S. CODE Cong. \& AD. News 1119.21.

8. 18 U.S.C. $\$ \$ 3575-78$ (1970), provides a thirty-year sentence for habitual and otherwise "dangerous" offenders; those with racketeering backgrounds are defined as dangerous under the statute.

9. 18 U.S.C. $\$ 1955$ (1970); Perez v. United States, 402 U.S. 146 (1971) (\$ 195J held constitutional).

10. 18 U.S.C. $\$ \S 1961-68(1970)$. Two procedural sections were enacted to aid in the enforcement of $\$ 1962$. I8 U.S.C. $\$ \S 1964,1968$ (1970). Section 1964 provides that the Attorney General may proceed in a civil action against a racketeer who violates any part of $\S 1962$ and outlines the penalties to be imposed. The purpose of these provisions, see Senate Hearings, supra note 4, at 151-52, 393-96, 405-08; SENATE REPORT, supra note 4 , at $79-83$, 125.26, was probably to permit the Attorney General to skirt the bounds of criminal safeguards. The potential for abuse of the power to proceed civilly as well as criminally has been noted in another context. Duke, Prosecutions for Attempts to Evade Income Tax: A Discordant View of a Procedural Hybrid, 76 YALE L.J. 1 (1966).

Section 1968 describes the "civil investigative demand." Civil investigative demand is a term of art borrowed from antitrust law. See P. AREEDA, ANTrrrust ANALYsIs 43-44 (1967). Through the use of this technique, a witness can be compelled to testify and to produce documents, apparently even if the evidence so supplied would tend to incriminate him. See Duke, supra, at 49.

11. A special committee of the American Bar Association has insisted that the evidence is clear that organized crime, which takes billions of dollars-mostly in cash and mostly untaxed-annually from the American public, has broadened its operations by infiltrating and taking over legitimate businesses.... Organized crime, therefore, is a major threat to the proper functioning of the American economic system .... When organized crime moves into a business, it customarily brings all the techniques of violence and intimidation which it used in its illegal businesses.

SENATE RePORT, supra note 4, at 76.

The list of legitimate businesses in which organized crime is reputedly involved includes advertising, florist shops, car dealerships, football franchises, real estate, and securities. SENATE REPORT, supra note 4 , at 76-77. The methods used to gain control over such legitimate businesses reportedly are extortion, violence, collection of gambling or loan shark debts, and various "scams," e.g., bankruptcy frauds, and collecting insurance after the deliberate arson of a business which failed to repay a loan. Id. at 77. This information was supplied by the Justice Department; the Department provided no further detail. See 8 BNA CrIM. L. REP. 2060 (1970) (speech by Att'y Gen. Mitchell to American Bankers Ass'n, on infiltration of the banking industry).

12. 18 U.S.C. $§ 1962$ (1970). 
offenses: (1) investment of "dirty money," i.e., income earned or derived from illegal racketeering activity; ${ }^{13}$ (2) takeover and control of a business through racketeering activity; ${ }^{14}$ and (3) operation of a business through racketeering activity. ${ }^{15}$ "Racketeering activity" is a shorthand phrase for those offenses believed to be commonly and frequently committed by organized crime figures. ${ }^{16}$

\section{18 U.S.C. $\$ 1962$ (a) (1970):}

It shall be unlawful for any person who has received any income derived, directly or indirectly, from a pattern of racketeering activity or through collection of an unlawful debt in which such person has participated as a principal within the meaning of section 2, Title 18, United States Code, to use or invest, directly or indirectly, any part of such income or the proceeds of such income, in the acquisition of any enterprise which is engaged in or the activities of which affect interstate or foreign commerce. A purchase of securities on the open market for purposes of investment, and without intention of controlling or participating in the control of the issuer, or of assisting another to do so, shall not be unlawful under this subsection if the securities of the issuer held by the purchaser, the members of his immediate family, and his or their accomplices in any pattern of racketeering activity or the collection of an unlawful debt if such purchases do not amount in the aggregate to one percent of the outstanding securities of any one class, and do not confer, either in law or in fact, the power to elect one or more directors of the issuer.

14. 18 U.S.C. $\$ 1962(\mathrm{~b})(1970)$ :

It shall be unlawful for any person through a pattern of racketeering activity or through collection of an unlawful debt to acquire or maintain, directly or indirectly, any interest in or control of any enterprise which is engaged in, or the activity of which affects interstate or foreign commerce.

15. 18 U.S.C. $\$ 1962$ (c) $(1970)$ :

It shall be unlawful for any person employed by or associated with any enterprise engaged in or the activities of which affect interstate or foreign commerce, to conduct such enterprise's affairs through a pattern of racketeering or through collection of an unlawful debt.

16. 18 U.S.C. $\$ 1961$ (1970) defines "racketeering activity" as any one of roughly thirty-five offenses. Among these are the most serious offenses in Title 18. The following is a list of the offenses and their maximum penalties. Those in Title 18 of the 1970 edition of the United States Code include $\$ 1111$ (murder in the first degree) death or life imprisonment; $\$ 1111$ (murder in the second degree) life imprisonment or any term of years; $\$ 1112$ (manslaughter) 10 years; $\S 1201$ (kidnapping) life or any term of years; $\$ 1202$ (transportation and possession of ransom money) $\$ 10,000,10$ years, or both; $\$ \S 1081-84$ (personal gambling) varying penalties; $\$ 81$ (arson) $\$ 1,000,5$ years, or both $(\$ 5,000,20$ years, or both if someone endangered) $\$ 2111$ (maritime robbery) 15 years; $\$ 2112$ (theft of government property) 15 years; $\$ 2113$ (bank robbery) $\$ 5,000,20$ years, or both; $\$ \S 1001-02$ (general fraud) $\$ 10,000$ 5 years, or both; $\$ 152$ (bankruptcy fraud) $\$ 5,000,5$ years, or both; $\$ 201$ (bribery) $\$ 10,000,2$ years, or both; $\$ 224$ (sports bribery) $\$ 10,000,5$ years, or both; $\$ \$ 471-73$ (counterfeit securities) $\$ 5,000,15$ years, or both; $\$ 659$ (felonious theft from interstate commerce) $\$ 5,000,10$ years, or both; $\$ 664$ (embezzlement from pension fund) $\$ 10,000$, 5 years, or both; $\$ \$ 891.94$ (extortionate credit transactions) $\$ 10,000,20$ years, or both; $\$ 1341$ (mail fraud) $\$ 1,000,5$ years, or both; $\$ 1343$ (wire fraud) $\$ 1,000,5$ years, or both; $\$ 2503$ (jury or witness tampering) $\$ 5,000,5$ years, or both; $\$ 1510$ (obstruction of criminal investigation) $\$ 5,000,5$ years, or both; $\$ 1511$ (obstruction of enforcement of gambling laws) $\$ 20,000,5$ years, or both; $\S 1951$ (interference with commerce by threats or violence) $\$ 10,000,20$ years, or both; $\$ 1952$ (travel in aid of racketeering enterprise) $\$ 10,000,5$ years, or both; $\$ 1953$ (interstate transportation of wagering paraphernalia) $\$ 10,000,5$ years, or both; $\$ 1954$ (influencing operation of employee benefit plan) $\$ 10,000,3$ years, or both; $\$ 1955$ (operation of illegal gambling business) $\$ 20,000$, 5 years, or both; $\$ 2314$ (interstate transportation of stolen property) $\$ 10,000,10$ years, or both; $\$ 2315$ (sale or receipt of stolen property) $\$ 10,000$, 10 years, or both; $\$ 2421$ (transporting female for white slavery), $\$ 5,000,5$ years, or both; $\$ 2422$ (causing female to be transported for white slavery) $\$ 5,000,5$ years, or both; $\$ 2423$ (causing 
The criminal penalty imposed for a violation of any of the prohibitions of $\S 1962$ is a fine of $\$ 25,000$, imprisonment for twenty years, or both, plus forfeiture of any interest the defendant has acquired or maintained in a business in violation of Title IX.17 These offenses carry the most severe maximum penalty authorized in Title 18 of the United States Code except for homicide offenses. ${ }^{18}$

This Note will examine $\S 1962(a),{ }^{19}$ the prohibition against investment of "dirty money." This subsection deserves critical examination, first, because its language raises difficult problems of statutory interpretation, ${ }^{20}$ which, once resolved, may result in increasing the government's burden of proof beyond that burden contemplated by the advocates of $\S 1962(a)$. This Note will explore the ambiguities in the Act and suggest a construction to resolve those ambiguities. Second, because the Act on its face imposes no mens rea requirement, the Note examines this omission and proposes a mens rea standard for $\S 1962(a)$. Third, the Note evaluates the problems of proof the Act presents and concludes that it defined a largely unprovable crime. The Note, therefore, recommends that Congress in its present deliberations on recodification of Title $18^{21}$ con-

minor female to be transported for white slavery) $\$ 10,000,10$ years, or both; $\$ 2424$ (failure to report alien status of resident of house of prostitution) $\$ 2,000,2$ years, or both. Those outside Title 18 include 21 U.S.C. $\$ \S 801-966$ (Drug Prevention Control and Treatment Act) varying penalties depending on offense; 29 U.S.C. $\$ 186$ (illegal payments to labor organization) $\$ 10,000,1$ year, or both; 29 U.S.C. $\$ 501$ (embezzlement of union funds) $\$ 10,000,5$ years, or both.

17. 18 U.S.C. $\S 1963(1970)$ restores the use of criminal forfeiture, a penalty which was abolished by the first Congress. See Act of April 30, 1790, ch. 9, $\$ 24,1$ Stat. 117 .

18. See note 16 supra.

19. There have been no convictions or indictments under $\$ 1962$ (a) since it was passed. Letter from Ass't Att'y Gen. Henry Petersen to author, Mar. 23, 1973 (on file with the Yale Law Journal). Section 1962(a) has thus never been interpreted by the courts. In King v. Vesco, 342 F. Supp. 120 (N.D. Cal. 1972), the court interpreted the venue provisions of the civil enforcement section, but did not pass on any substantive ambiguities in $\$ 1962$.

20. It is unclear whether the statute is sufficiently vague to run afoul of the "void for vagueness" doctrine. This doctrine has in the past generally been applied only to criminal statutes which potentially infringe First Amendment rights. See Grayned v. Rockford, 408 U.S. 104 (1972); Papachristou v. City of Jacksonville, 405 U.S. 156 (1972); Coates v. City of Cincinnati, 402 U.S. 611 (1971); Baggett v. Bullitt, 377 U.S. 360 (1964); United States v. National Dairy Prods. Corp., 372 U.S. 29 (1963); United States v. Harriss, 347 U.S. 612 (1954). McGautha v. California, 402 U.S. 183, 250-70 (1971) (Brennan, J., dissenting); Amsterdam, Federal Constitutional Restrictions on the Punishment of Crimes of Status, Crimes of General Obnoxiousness, Crimes Displeasing Police Officers, and The Like, 3 Crim. L. Bull. 205 (1967); see generally Note, The Void-for-Vagueness Doctrine in the Supreme Court, 109 U. PA. L. REv. 67 (1960).

21. Title 18 of the United States Code is presently undergoing another revision and recodification. See Note, Piggyback Jurisdiction in the Proposed Federal Criminal Code, 81 YALE L.J. 1209 (1972). Two of the three proposed revisions would apparently retain $\S 1962$ (a) in essentially its present form. See S.1, $\S 2-9 C(a)(2), 93 \mathrm{~d}$ Cong., 1st Sess. (1973); S.1400, $\$ 1861$ (a)(2), 93d Cong., 1st Sess. (1973). On the other hand, the National Commission on Reform of Federal Criminal Laws recommends no provisions analogous to $\$ 1962$ (a). See National Comm'N ON Reform of Federal Criminal Laws, FINAL REPORT (1970), reprinted in Hearings on Reform of the Federal Criminal Laws Before the Senate Comm. on the Judiciary, 92d Cong., Ist Sess., pt. 1, at 129 (1971). 
sider drastic amendment of $\S 1962(a)$ or its elimination from the United States Code.

Section 1962(a), despite its deceiving simplicity, is an extremely ambiguous statute and raises difficult problems of statutory construction. The first problem concerns the scope of the section, i.e., who is a proper defendant under $\S 1962(a)$. While the statute, as reflected in its popular name, appears to be aimed at investment of "dirty money" by organized crime figures, the language of the statute can be read to cover persons not associated with organized crime but who have either received money from organized crime activity or who have committed crimes associated with organized crime figures. The second problem of statutory construction involves the relation of $\S 1962$ (a) to the statute of limitations, viz., whether a $\S$ 1962(a) prosecution can be used to circumvent the bar of the statute for crimes which are alleged to prove a "pattern" of criminal activity. The third problem of statutory construction involves the usage in the statute of the word "proceeds."

Section 1962(a) is clearly aimed at the person who invests the proceeds of his own racketeering activity. ${ }^{22}$ However, the unqualified generality of the words "any person who has received any income derived, directly or indirectly, from a pattern of racketeering activity," raises the issue of whether $\S$ 1962(a) extends to persons who did not commit any racketeering acts but who receive money or other income from a racketeer and then use it in their businesses, with no intent to make the income of those businesses primarily available for further racketeering activity. ${ }^{23}$ Consider, for example, the following situation: A racketeer gives money to a person who has not committed acts of racketeering and with whom the racketeer wishes to ingratiate himself; the money is an investment

22. 18 U.S.C. $\$ 1962(a)(1970)$ states that "any person who has received any income derived, directly or indirectly, from a pattern of racketeering activity or through collection of an unlawful debt ..." is liable under the statute. (Emphasis added).

23. A suggested interpretation in the SENATE REPORT, supra note 4 , at 158 , seems at first glance to resolve the ambiguity:

The term "racketeering activity" is a key statutory term. Under proposed section

1962, below, the racketeering activity is one of the three prerequisites to com-

mission of an offense.

However, even this is insufficient as a precise explanation and limitation of the scope of $\S 1962(a)$. While the Report notes that there must be racketeering activity for a violation to occur, it does not indicate whether the person who committed the racketecring acts must be the same person who is indicted under $\$ 1962$ (a). The reason for the continted confusion is that the phrase "proceeds of such income" would seem to implicate someone who had not himself committed any racketeering acts. 
in the person's business, not a bribe. ${ }^{24}$ Would the innocent (nonracketeering) taker be a potential defendant under $\S 1962$ (a)? Since such a businessman has received income "indirectly" from a racketeering activity he arguably could be considered a defendant under the Act. ${ }^{25}$ The inclusion of the clause "in which such person has participated as a principal" was presumably intended to clear up this ambiguity, but it is not clear from the placement of the clause in the statute whether it modifies "a pattern of racketeering activity" as well as "the collection of an unlawful debt," or just the latter phrase. $^{26}$ If it modifies only the latter phrase, the innocent taker could be a potential defendant under $\S 1962(\mathrm{a})$.

Congress should clarify the uncertainty in statutory language, presumably by making it clear that the clause modified both phrases. In the meantime, courts should apply accepted principles of criminal responsibility in construction of the statute. If the taker knew that the investor was a racketeer and thus that the funds might have been derived from racketeering activity, but had no other connection with the racketeering activity, he would, if he is criminally liable at all, probably be considered an accessory after the fact ${ }^{27}$ to

24. For example, if a man whose brother is in the city government is starting a new business and needs capital, the racketeer may become an investor. The racketeer would arguably be chargeable under $\$ 1962(a)$. The question is whether the new businessman would also be chargeable, since he "used" money derived from a pattern of racketeering activity.

25. A court could define the word "income" consistent with the tax definition, thus excluding bona fide loans or capital contributions from the term. See INT. Rev. Cone of $1954 \$ \$ 102,118$; James v. United States, 366 U.S. 213 (1961); United States v. Rochelle, 384 F.2d 748 (5th Cir. 1967), cert. denied, 390 U.S. 946 (1968). However, such an approach might well be too mechanical. For example, if a racketeer received from another racketeer a payment which could be conceptualized as a "loan" or a "capital contribution," a tax definition of "income" would exclude investment of such income from the scope of $\$ 1962$ (a). A broad and flexible concept of income may well be preferable. Similar difficulties surround a judicial definition of the word "indirectly"; limiting the meaning of "indirectly" to only the proceeds of racketeering conducted by subordinates or co-conspirators may put interpretative pressure on that definition and permit the exclusion of racketeering proceeds from the statute's operation. For example, if a racketeer invested the proceeds of illegal activity into a front business and then, after "cleaning" the money (i.e., passing it through a legitimate income producing operation) invested in another business he intends to subvert, a narrow definition of "indirectly" might exclude that second investment from the scope of $\S 1962(a)$.

26. See 18 U.S.C. $\S 1962$ (a) (1970), quoled in full in note 13 supra. A proposed revision of $\S 1962(a)$, S.I, $\$ 2.9 \mathrm{Cl}(\mathrm{a})(2)$, 93d Cong., 1st Sess. (1973), would substitute the word "accomplice" for the word "principal."

27. 18 U.S.C. $\$ 3$ (1970):

Accessory after the fact: Whoever, knowing that an offense against the United States has been committed, receives, relieves, comforts, or assists the offender in order to hinder or prevent his apprehension, trial or punishment, is an accessory after the fact.

Except as otherwise provided by any Act of Congress, an accessory after the fact shall be imprisoned not more than one-half the maximum term of imprison- 
the $\S 1962(a)$ violation. ${ }^{28}$ Accessories after the fact, under present federal law, face no liability for the crime itself, but only for obstruction of justice or for interference with a criminal investigation. ${ }^{29}$ Since Congress, in enacting OCCA-70, did not state that it intended to change this rule, courts should hold that the taker who merely knew that the investor was a racketeer is not a potential defendant under $\$ 1962(a)$.

If the taker not only knew that the investor was a racketeer, but also had some indirect connection with the racketeering activity from which the funds were derived, that is, did not commit the racketeering acts himself, but rather counseled the actor or solicited the activity, he would probably be considered an accessory before the fact and be liable equally with the principal for the racketeering activity as a principal. ${ }^{30}$ An example of this status is the organized crime figure who is a "skimmer's" superior. ${ }^{31}$ Courts should construe $\S$ 1962(a) broadly enough to include such persons, because they would be "principals" in the crime of investment.

If, however, $\$ 1$ 1962(a) is given a broad reading, that is, if its purpose is to restrict the seemingly "legitimate" activities of racketeers as well as their illegal activities in an effort to deter the intervention of organized crime into legitimate business, then both the hypothetical businessman and the skimmer's superior would be potential defendants under the statute. ${ }^{32}$

ment or fined not more than one-half the maximum fine prescribed for the punishment of the principal, or both; or if the principal be punishable by death, the accessory shall be imprisoned not more than ten years.

Accord, Model Penal Code $\$ 2.06$ (Prop. Official Draft, 1962).

28. If the investor did not know that the money was derived from racketeering activity, he may not be criminally liable at all. See pp. 1502-10. If he knew that the money was "dirty" then he would be liable as an accessory after the fact. 18 U.S.C. $\$ 3(1970)$. However, while the matter is not free from doubt, it would appear that such a person would not be an "aider and abettor," and hence a principal, because he would lack the necessary criminal intent. An "aider and abettor" must "willfully and knowingly" associate himself with the criminal intent of the principal; "mere presence at the scene of the crime" is not sufficient. Hicks v. United States, 150 U.S. 442 (1893); United States v. Austin, 462 F.2d 724,732 (10th Cir.), cert. denied, 409 U.S. 1126 (1972); United States v. Bryant, 461 F.2d 912, 919-22 (6th Cir. 1972); Snyder v. United States, 448 F.2d 716, 718 (8th Cir. 1971). Since it is unlikely that the hypothetical defendant shared in the racketeering activity and subsequent investment "wilfully and knowingly," he would not be an aider and abettor. If it could be proven that the hypothetical defendant knew that the money he received was "dirty" and that the investor was a racketeer, the case would perhaps go the other way. The central issue seems to involve the definition of the proper mens rea for the crime itself, a subject which will be explored in more detail in pp. 1502-10 infra.

29. See Virgin Islands v. Acquino, 378 F.2d 540, 553 (3d Cir. 1967); Skelly v. United States, 76 F.2d 483, 488 n.3 (10th Cir.), cert. denied, 295 U.S. 757 (1935).

30. See 18 U.S.C. $\$ 2$ (1970); Robinson v. United States, 262 F.2d 645 (9th Cir. 1959); Morei v. United States, 127 F.2d 827 (6th Cir. 1942); note 24 supra.

31. A "skimmer" removes a percentage of profits from legal gambling houses for distribution to various underworld figures, his superiors.

32. See p. 1507 infra. 
Another ambiguity as to who are proper defendants under $\$ 1962$ (a) is whether the person indicted thereunder must be a member of a criminal syndicate. ${ }^{33}$ Nothing in $\$ 1962$ (a) or any other part of OCCA70 specifically imposes on a prosecutor the requirement of proving that a person indicted under $\S 1962(\mathrm{a})$ is a member of a criminal syndicate. However, the intended focus of the section, as reflected in the Findings and Purposes, ${ }^{34}$ indicates that the dangers posed by criminal syndicates are the raison d'etre of the Act. ${ }^{35}$ The particularly harsh penalties imposed on a violator of $\S 1962$ (a) are presumably justified by Congress' view of the seriousness of the threat of organized crime-not the threat posed by ordinary, independent criminals. It is true that it would be difficult to prove an individual accused's membership in a specific criminal syndicate. If the statute's penalties are to be imposed on the proper persons, however, proof

33. Despite the intensive debate of the subject, see note 4 supra, Congress apparently is convinced that a monolithic criminal organization exists and drafted OCCA-70 to cope with it. See SENATE REPORT, supra note 4, at 35-43; Senate Hearings, supra note 4, at 107 , 114, 124-28; cf. United States v. Podell, 369 F. Supp. 151, 154.55 (S.D.N.Y. 1974) (OCCA-70 provisions permitting depositions to preserve testimony, 18 U.S.C. $\$ 3503$ (1970), limited to organized crime figures, a fact which by statute the Attorney General must certify to; court may look behind this certification to determine that organized crime figures are involved).

In In re Kilgo, 484 F.2d 1215 (4th Cir. 1973), the court held that OCCA.70 immunity provisions were not limited to use against organized crime figures. As the court noted, $i d$. at 1217-18, those immunity provisions were a codification of prior general immunity statutes and were not enacted specifically to deal with organized crime, as the history of $\$ 1962(a)$ indicates that it was. See note 11 supra.

34. Pub. L. No. 91-452, $\$ 1,84$ Stat. 922 (Statement of Findings and Purposes):

The Congress finds that (1) organized crime in the United States is a highly sophisticated, diversified, and widespread activity that annually drains billions of dollars from America's economy by unlawful conduct and the illegal use of force, fraud and corruption; (2) organized crime derives a major portion of its power through money obtained from such illegal endeavors as syndicated gambling, loan sharking, the theft and fencing of property, the importation and distribution of narcotics and other dangerous drugs, and other forms of social exploitation; (3) this money and power are increasingly used to infiltrate and corrupt legitimate business and labor unions and to subvert and corrupt our democratic processes; (4) organized crime activities in the United States weaken the stability of the Nation's economic system, harm innocent investors and competing organizations, interfere with free competition, seriously burden interstate commerce, threaten domestic security, and undermine the general welfare of the Nation and its citizens; and (5) organized crime continues to grow because of defects in the evidence-gathering process of the law inhibiting the development of the legally admissible evidence necessary to bring criminal and other sanctions or remedies to bear on the unlawful activities of those engaged in organized crime and because the sanctions and remedies available to the Government are unnecessarily limited in scope and impact.

It is the purpose of this act to seek the eradication of organized crime in the United States by strengthening the legal tools in the evidence gathering process, by establishing new penal prohibitions, and by providing enhanced sanctions and new remedies to deal with the unlawful activities of those engaged in organized crime.

35. See notes 4, 5 \& 11 supra and 112 infra; McClellan, The Organized Crime Control Act (S.30) or its Critics: Which Threatens Civil Liberties?, 46 NOTRE DAME LAw. 55 (1970). 
of this connection seems necessary. ${ }^{36}$ This ambiguity is seemingly resolved by the requirement of a "pattern of racketeering activity." The term "pattern" suggests continuing, interdependent criminal activity; as used in the statute, however, the term "pattern" does not necessarily require proof of membership in a criminal syndicate.

The Act prohibits investment of money derived from a "pattern of racketeering activity." A "pattern of racketeering activity" exists under the terms of $\S 1962$ (a) if the accused has committed "at least two acts of racketeering activity, one of which occurred after the effective date of this chapter and the last of which occurred within ten years (excluding any period of imprisonment) after the commission of a prior act of racketeering activity ...."37 In common usage, the term "pattern" is applied to a combination of qualities or acts forming a consistent or characteristic arrangement. Use of the term pattern in connection with two racketeering acts committed by the same person suggests that the two acts must have greater interrelationship than simply commission by a common perpetrator. It is not clear, however, if the two acts were intended by the drafters to be related, and, if so, how. The acts could be related, for example, if they involve the violation of the same substantive law, that is, both involving bribery or both involving the use of extortionate methods. The acts could also be related if they were part of a particular continuing criminal activity, e.g., interstate transportation of wagering paraphernalia and operation of an illegal gambling business, rather than isolated occurrences. The acts could even be minimally related if they were committed by a member of a criminal syndicate. Nothing in the definition of "pattern of racketeering activity" quoted above, however, requires proof of any such interrelatedness. ${ }^{38}$ Thus, as it is presently written, $\S 1962$ (a) could be used against an independent criminal ${ }^{39}$ who in no sense was the intended target of $\$ 1962(a) .40$

36. Ambiguous statutory language is generally interpreted with a view to its purpose, whether the statute is criminal or not. See United States v. Brown, 333 U.S. 18 (1948); United States v. American Trucking Ass'n, 310 U.S. 534 (1940); Standard Oil Co. v. United States, 221 U.S. 1 (1911). A court, faced with this rather unclear statute, could with considerable justification limit its application to those persons proved to be members of criminal syndicates.

37. 18 U.S.C. $\$ 1961(5)(1970)$.

38. But cf. S.I, \$ 2-9Cl(a)(2), 93d Cong., Ist Sess. (1973) (would amend $\$$ 1962(a)

to have it read "two or more related, not isolated, acts of racketeering activity").

39. For the list of crimes designated as "racketeering activity" see note 16 supra. No claim is made that only organized crime figures commit such crimes.

40. A more acceptable definition of pattern is contained in a suggested revision of the Federal Criminal Code, see S.1400, $\$ 1861(\mathrm{~b})(2), 93 d$ Cong., 1st Sess. (1973):

Pattern of racketeering activity means two or more separate acts of racketeering 
A further ambiguity in $\S 1962$ involves the meaning of the word "acts." It is unclear whether two prior racketeering convictions would be necessary. Conceivably, a $\$ 1962$ (a) conviction could be based on two prior racketeering "acts" for which the defendant was never convicted. The definition of the term "acts" would be crucial when a prosecution is commenced for investment on the basis of a prior racketeering act if the prosecution of that act today would be barred by the statute of limitations. ${ }^{41}$

The use of the word "act" instead of "conviction" suggests that the drafters suspected that a typical defendant under $\$ 1962$ would probably not have been convicted of the prior racketeering acts. The following situation may have been envisaged as typical: $A$ person who committed two acts of racketeering, one in 1960 and one in 1970, invested in 1972. He has not been convicted of the prior racketeering acts and these acts are the only acts for which the government now has proof. He could be charged with and tried for the 1970 racketeering offense and the 1972 investment but he could neither be charged with nor tried for the 1960 offense, because the statute of limitations on that offense has run. The question is whether the government could nevertheless use its proof of the 1960 offense as part of its case against the defendant under $\S 1962(a)$. The statute's use of the term "acts" instead of "convictions" suggests that the answer would be affirmative.

This explanation of the use of the term "acts" rather than "convictions" is admittedly speculative. What motivated Congress does not appear on the face of the statute, and there are no clues to be found in the legislative history of OCGA-70. The drafters may have weighed the policy considerations underlying the statute of limita-

activity, committed after October 15, 1970 [effective date of OCCA.70], which have the same or similar purposes, results, participants, victims, or methods of commission or otherwise are interrelated by distinguishing characteristics and are not isolated events.

41. See 18 U.S.C. $\$ 3283$ (1970) (five year statute of limitations for noncapital offenses). An explicit attempt to avoid the statute of limitations is contained in a proposed revision of $\S 1962(\mathrm{a})$. See S.1, $\$ \S 1-3 \mathrm{Bl}(\mathrm{g}), 2.9 \mathrm{Cl}(\mathrm{c})$, 93d Cong., 1st Sess. (1973).

$\$ 1-3 \mathrm{Bl}(\mathrm{g})$ provides:

Notwithstanding that the period of limitations has expired, a prosecution is timely commenced (1) for an offense included in the offense charged, if as to the offense charged the period of limitation has not expired . . . and there is, after the evidence on either side is closed at trial, sufficient evidence to sustain a conviction of the offense charged ....

$\$ 2-9 \mathrm{Cl}(\mathrm{a})$ states:

Offense-A person is guilty of racketeering activity if:

(2) having received income from a pattern of racketeering activity or through the

collection of an unlawful debt, in the conduct of which he was an accomplice, he:

(i) uses, or

(ii) invests

any part of such income or the proceeds of such income in the acquisition of any interest in or the establishment or operation of any enterprise. 
tions ${ }^{42}$ against the desirability of successfully prosecuting racketeers and decided that the latter was more important. However, had Congress expressly wanted to revise the statute of limitations to include the above-described situation, it certainly could have done so. It chose not to; it chose instead to use the ambiguous term "acts." A resolution of the ambiguity would seem to require either a revision of the statute of limitations or the replacement of the term "acts" with the term "convictions." Congress should, therefore, at a minimum amend the statute to deal with this ambiguity. In the meantime courts should follow the principle of statutory construction which resolves all ambiguities in favor of the policy of repose underlying the statute of limitations ${ }^{43}$ and interpret the word "acts" to mean "convictions" whenever the government alleges racketeering acts upon which conviction is barred by the statute of limitations.44

Another ambiguity in $\S 1962$ (a) involves the use of the term "proceeds." The definition of this term will be crucial in determining the scope of the one exception contained in $\$$ 1962(a): A racketeer may purchase stocks on the open market with "dirty money" as long as his holdings do not exceed one percent of the total outstanding securities of the issuer. ${ }^{45}$ If the racketeer could "clean" all of his

42. Four policy reasons underlying the statute of limitations are: (1) the desirability of convictions based on fresh evidence, (2) the value to defendants of being freed of the fear of prosecution, (3) the reduced demand for retribution as time passes, and (4) the reduced need for rehabilitation as time passes (if the defendant does not commit any other criminal acts). See Model. PeNal Code $\$ 1.07$, Comment (Tent. Draft No. 5, 1956), at 16-17. See People v. Hryciuk, 36 Ill. 2d 500, 224 N.E.2d 250 (1967); Note, The Right to a Speedy Trial, 20 STAN. L. Rev. 476, 485-93 (1968).

43. See United States v. Marion, 404 U.S. 307, 322 n.14 (1971); United States v. Orcgon Lumber Co., 260 U.S. 290, $299-300$ (1922); United States v. Moriarty, 327 F. Supp. 1045, 1047 (E.D. Wis. 1971); Jones v. Rabinowitz, 296 F. Supp. 123, 125 (E.D. Pa. 1969); Atkins v. Schmutz MIf. Co., 268 F. Supp. 406, 408 (W.D. Va. 1967), aff'd, 401 F.2d 731 (4th Cir. 1968), cert. denied, 402 U.S. 932 (1971); United States v. Gross, 159 F. Supp. 316,317 (D. Nev. 1958).

44. If the term "acts" were not so interpreted, the statute might also raise a serious double jeopardy problem in the following situation: A defendant was tried for an act which is now included within $\$ 1961$, see note 16 supra, prior to the passage of OCC.1-70 and was acquitted; after the passage of the Act, he is tried on a $\$ 1962$ (a) charge and evidence of the previous racketeering act upon which the defendant was tried constitutes the government's proof of one of the two racketeering "acts." The defendant is thus forced to prove himself innocent twice, a requirement inconsistent with the purposes of the double jeopardy clause. Cf. Ashe v. Swenson, 397 U.S. 436, 443 (1970); United States v. Ball, 163 U.S. 662, 669 (1896). This view of double jeopardy involves a res judicata principle. See Moore's Federal Practice $\$ 0.148$ [2], at 2763-74 (2d ed. 1965); Lugar, Criminal Law, Double Jeopardy and Res Judicala, 39 IowA L. REv. 317, 319, 329 (1954); Perkins, Collateral Estoppel in Criminal Cases, 1960 ILL. L.F. 533, 561-71. This problem could be solved if "acts" were interpreted to mean "convictions" in the above-described circumstances since the res judicata principles underlying double jeopardy would be inapplicable if the prior issue was resolved against the defendant.

45. 18 U.S.C. $\$ 1962$ (a) (1970). The rationale of the exception to $\$ 1962$ (a) is not immediately apparent. One possible explanation is that it was required by Powell v. Texas, 392 U.S. 514 (1968), which was handed down while the statute was being drafted. The issue in Powell was whether a statute which made public drunkenness a 
dirty money by investing it within the exception to $\S 1962$ (a) and then reinvest the proceeds of these initial investments outside the exception (e.g., in a legitimate business), the deterrent effect of the Act would be seriously impaired. A broad construction of the term "proceeds" 46 would prevent a racketeer from circumventing $\$$ 1962(a) by first investing in securities within the one percent exemption.

\section{II}

The most serious ambiguity in the language of $\$ 1962(\mathrm{a})-\mathrm{an}$ ambiguity which raises additional difficult issues of statutory interpretation and which poses troubling questions about the compatibility of OCCA-70 with the American system of criminal justice-is the apparent lack of a mens rea requirement. An analysis of this issue requires an initial examination of the purposes of criminal laws and the role mens rea plays with regard to those purposes.

There are essentially two types of criminal laws. Laws of the first type are those which prohibit certain behavior because it is harmful per se or deemed harmful when measured against some higher, moral law; this type of criminal law can be labeled "wrong on principle." Acts which fall into this category are made criminal not solely because society believes that their proscription will necessarily prevent the reoccurrence of such behavior (although society has that hope), but also because the behavior is considered wrong in and of itself. Behavior which is wrong on principle is considered "blameworthy," and society would proscribe such behavior even if the proscription clearly would not prevent the occurrence of such behavior. Murder,

crime was invalid on the authority of Robinson v. California, 370 U.S. 660 (1962), which had invalidated laws punishing "status" as cruel and unusual under the Eighth Amendment. The majority opinions in Powell held that the statute punished the act of public drunkenness rather than the status of being a drunk, since a person would not violate the statute if he drank only in private. 392 U.S. at 532, 538, 541-44, 548-49, 553-54.

The drafters of $\$ 1962(a)$ may have read Powell to render a statute unconstitutional which penalized any investment of proceeds of racketeering activity because it would punish the "status" of being a racketeer. This possibility though is speculative and farfetched. For it seems clear that even a statute which punished all investment would pass muster under Robinson and Powell: The person with ill-gotten gains need not invest his tainted money and enrich himself further. He may return the dirty money to its rightful owner, give the money away, or spend it on consumer goods. It is his conduct, his investment of dirty money, which is punished, not his status.

46. The definition of "proceeds" contained in UNIFORM CoMmercial CodE $\$$ 9.306 would provide the basis for such a broad reading:

"Proceeds" includes whatever is received upon the sale, exchange, collection or other disposition of collateral or proceeds . . . Money, checks, deposit accounts and the like are "cash proceeds," all other proceeds are "non-cash proceeds." 
theft, and common law crimes ${ }^{47}$ are examples of behavior which is "wrong on principle."

Laws of the second type are those which prohibit certain behavior in order to effect some social policy; that is, society believes that by outlawing act $X$ it will be able to achieve policy $Y$. If society did not believe that outlawing act $X$ would achieve policy $Y$, it would not prohibit $X$. In short, behavior $X$ is not considered "blameworthy." 48 Society forbids child labor in large part to promote children's welfare and safety; society prohibits the accidental inaccurate labeling of drugs to guard against improper drug use and prevent drug poisoning. ${ }^{40}$ Of course, the proscribed behavior might be considered somewhat "wrong on principle," but such a rationale is the weak rather than the strong justification for adjudging such behavior criminal. 00 This second type of criminal law thus prohibits behavior which is "wrong for policy reasons."

In an overall sense, all criminal laws are motivated by policy reasons-that is, the promotion of public health, welfare and safety. The distinction between that conduct which is "wrong on principle" and that which is "wrong for policy reasons" is one which is easily collapsed. The basis of the distinction, however, is this: Conduct which is considered "wrong on principle" has an element of blameworthiness; blameworthiness is not significantly present in conduct which is considered "wrong for policy reasons." The distinction is thus not based on the "harmfulness" of the conduct.".1

The primary functional difference between crimes which are "wrong on principle" and those "wrong for policy reasons" involves the intent of the actor. Crimes which are "wrong on principle" are

47. See Morissette v. United States, 342 U.S. 246, 250-52, 260-62 (1952); J. BenthaM, Introduction to THE Principles of Morals and Legislation 70-87, 204, 207, $213-21$ (1907); J. Hall, General Principles of Criminal Law 212.46 (2d ed. 1947); G. Williams, Criminal Law: The General Part 10-11, 592-96 (2d ed. 1960). See generally Model Penal Code $\$ 1.02(1)$ (a) (Tent. Draft No. 2, 1954 ; id., $\$ 2.04(2)$ (a) (Tent. Draft No. 1, 1953); Binivance, The Ethical Foundation of Criminal Liability, 33 FORD. L. REv. 1 (1964); Hart, The Aims of the Criminal Law, 23 LAw \& Contenp. Prob. 401 (1958).

48. See Morissette v. United States, 342 U.S. 246, 252.59 (1952); People v. Roby, 52 Mich. 577, 579, 18 N.W. 365, 366 (1884); Commonwealth v. Koczwara, $397 \mathrm{~Pa}$. 575, 155 A.2d 825 (1959). See generally Sayre, Public Welfare Offenses, 33 Colum. L. REv. 55 (1933). "The distinction between "principles" and "policies," as used in this Note, is treated at length by Professor Wellington. See Wellington, Common Law Rules and Constitutional Dotble Standards: Some Notes on Adjudication, 83 YALE L.J. 221, 222-54 (1973) [hereinafter cited as Common Law Rules]. See also Dworkin, Social Rules and Legal Theory, 81 YaLE L.J. 855 (1972).

49. See 21 U.S.C. $\$ 352$ (1970); 29 U.S.C. $\$ 212$ (1970); United States v. Dotterweich, 320 U S. 277. 284-85 (1943); Lenroot v. Interstate Bakeries Corp., 55 F. Supp. 234, 236 (W.D. Mo. 1944), modified, 146 F.2d 325 (8th Cir. 1945).

50. Cf. Common Law Rules, supra note 48 , at $222-23$.

51. Cf. id. at 224-25. 
"based upon a theory of punishing the vicious will. [They] postulate a free agent confronted with a choice between doing right and doing wrong and choosing freely to do wrong." "s2 If the actor did not in fact make that choice, but "accidentally" committed an otherwise criminal act, there would be no "crime" because there is no "blameworthiness" resulting from a free choice to do wrong. ${ }^{53}$ For crimes which are "wrong for policy reasons," such considerations do not apply. The law in such instances is unconcerned with the actor's "blameworthiness," since it punishes the effect of the acts rather than the "vicious will." 54

The law's concern with the intent of the actor is reflected in the doctrine of mens rea. The Supreme Court has repeatedly stated that criminal liability for an act will not be imposed unless the actor intended to commit the act, i.e., the actor must have acted with mens rea.55 Although the Supreme Court has stopped short of declaring that mens rea is a constitutional requirement in criminal statutes, ${ }^{503}$ it has generally construed penal statutes lacking the element of mens rea on their face to include such a requirement. ${ }^{57}$

52. Morissette v. United States, 342 U.S. 246, 250 n.4 (1952), citing Pound, Introduction to P. Sayre, Cases on Criminal Law (1927).

53. See O. Holmes, The Common Law 42 (DeWolfe ed. 1963): “criminal liability . . . is founded on blameworthiness." A particularly significant example of the requirement of mens rea or punishment of the "vicious will" and its relation to blameworthiness is found in the case law holding possessors of stolen goods innocent unless the state proves the possessor knew the goods were stolen. See United Statcs v. Koran, 453 F.2d 144 (10th Cir. 1972); Pauldino v. United States, 379 F.2d 170 (10th Cir. 1967); Corey v. United States, 305 F.2d 232 (9th Cir. 1962), cert. denied, 371 U.S. 956 (1963). To be sure courts have generally permitted an inference of such knowledge from unexplained possession shortly after the theft but the inference is limited to unexplained possession. See Barnes v. United States, 412 U.S. 837 (1973); United States v. Howard, 483 F.2d 229 (5th Cir. 1973), cert. denied, 94 S. Ct. 850 (1974); 9 J. Wigmore, EVIDENCE $\$ 2513$, at $417-24$ (3d ed. 1940).

54. See p. 1503 supra.

55. Smith v. California, 361 U.S. 147, 150 (1959); Lambert v. California, 355 U.S. 225, 228, 231 (1957); Morissette v. United States, 342 U.S. 246, 250.52 (1952); Dennis v. United States, 341 U.S. 494, 500 (1951); Screws v. United States, 325 U.S. 91, 101, 156 (1945).

56. See Dubin, Mens Rea Reconsidered: A Plea for a Due Process Concept of Criminal Responsibility, 18 Stan. L. REv. 322, 378-91 (1966); Packer, Mens Rea \& The Supreme Court, 1962 Sup. CT. REv. 107, 110-27. Professor Dubin in his lengthy article argues that constitutional due process concepts proscribe criminal punishment without proof of mens rea. Particularly, he argues that the requirements of definiteness and notice (see note 20 supra), the prohibition on ex post facto laws, and the Eighth Amendment combine to prohibit criminal punishment for acts the defendant could not under any standard of care avoid. See Dubin, supra, at $375-93$.

57. Scales v. United States, 367 U.S. 203 (1961); Morissette v. United States, 312 U.S. 246 (1952); Dennis v. United States, 341 U.S. 494 (1951), are cxamples of this variety of statutory construction; $c f$. United States v. Aluminum Co. of Am., 148 F.2d 416, 428-29 (2d Cir. 1945) (L. Hand, J.); People v. Vogel, 46 Cal. 2d 798, 299 P.2d 850 (1956); H. HART \& A. SAcKs, The Legal Process 1235-37 (Tent. ed. 1958); sources citcd in notes 55, 70 infra. But see United States v. Balint, 258 U.S. 250 (192.) (statute, construed by the Court not to require proof of mens rea, outlawed the sale of narcotics; while the Court noted that mens rea was usually a necessary element of a crime, this was not true of "statutory" crimes, even when harsh penalties are involved). 
Lambert v. California ${ }^{58}$ is a particularly dramatic example of the impact of the mens rea principle on statutory construction. The California statute scrutinized in Lambert made it an offense for a person who had been convicted of a felony to remain in a city for five days without registering with the police. The Court held that since the defendant's "default was entirely innocent" and since "no element of wilfullness is by terms included in the ordinance nor read into it by the California court[s]," there could be no conviction under the statute..$^{59}$ Justice Douglas, speaking for the Court, said that the statute failed to provide sufficient "notice" to a potential defendant and hence criminal liability could not be imposed. ${ }^{60} \mathrm{Al}$ though the usual rule is that ignorance of the law is not a defense, ${ }^{61}$ this rule was not applicable in Lambert because the statute involved was an unusual one. Specifically, Justice Douglas noted that the registration law was not the type of law that anyone, even a convicted felon, would have reason to believe existed..$^{22}$ Given this fact, mere failure to register could not be considered culpable; liability could not be imposed without some evidence that the defendant knew of the duty to register. Such evidence would amount to the government's showing that the defendant knowingly did not register, that is, that she intended not to register. A mens rea requirement was thus read into the statute. ${ }^{63}$

Social policy statutes, the penal statutes which prohibit certain behavior for policy reasons constitute the major exception to the rule that criminal liability will not be imposed unless mens rea is present. ${ }^{64}$ Indeed, Justice Frankfurter, in dissent in Lambert, while admitting that courts often, as a matter of statutory construction, "attribute to

58. 355 U.S. 225 (1958). See Packer, supra note 56, for a lengthy discussion of this case.

59. 355 U.S. at 227,229 .

60. See id. at 227-29.

61. See Long v. State, 44 Del. 262, 65 A.2d 489 (1949); Model Penal Code $\$ 2.04$

(Prop. Official Draft 1962); Packer, supra note 56, at 145.

62. 355 U.S. at 229.

63. The Court in Freed and Professor Packer both viewed Lambert as a mens rea case. See United States v. Freed, 401 U.S. 601, 608 (1971); Packer, supra note 56, at 127-37; note 69 infra.

64. Offenses such as felony-murder and statutory rape seemingly constitute exceptions to the rule that mens rea is required for all nonsocial policy crimes. See sources cited in Packer, supra note 56, at 140-42. These offenses, however, are hybrids; they contain dominant elements of blameworthiness, but also reflect certain social policies designed to deter felonies and sexual intercourse with underage women. In some jurisdictions recent cases seem to discourage recognition of such hybrids in favor of a uniform requirement of mens rea for all crimes (including pure social policy crimes). Sce, e.g., People v. Vogel, 46 Cal. 2d 798, 299 P.2d 850 (1956); Noble v. State, 248 Ind. 101, 223 N.E.2d 755 (1967); State v. Prince, 52 N.M. 15, 189 P.2d 993 (1948); People v. Post Std. Co., 13 N.Y.2d 185, 245 N.Y.S.2d 377, 195 N.E.2d 48 (1963); People v. Estreich, 272 A.D. 698,75 N.Y.S.2d 267 (1947). 
a statute the requirement of mental intent," argued that the registration law aimed at the "achievement of some social betterment rather than the punishment of crimes as cases of mala in se" and that such laws were clearly constitutional under numerous precedents. ${ }^{65}$

Courts have not been very precise in discussing the distinction between those crimes which require mens rea and those crimes which do not. The result is that many decisions speak in general terms of the relative severity of punishment imposed for different types of crimes, thus suggesting that the difference in penalties distinguishes crimes which require mens rea from crimes which do not.00 Whatever validity this view ever had, however, it surely cannot be maintained after United States $v$. Freed. ${ }^{67}$ The distinction apparently adopted in Freed is the one suggested earlier and seemingly adopted by Justice Frankfurter in his dissent in Lambert: ${ }^{88}$ Crimes which involve conduct "wrong on principle" must involve mens rea; crimes which involve conduct which is "wrong for policy reasons" need not. ${ }^{69}$ It follows that, in order to determine whether a statute will be inter-

65. 355 U.S. at $230-31$.

66. Traditionally, the penalties for violation of social policy criminal statutes were light, a fact commonly emphasized by courts upholding such statutes despite the lack of a mens rea requirement or interpreting such statutes not to require mens rea. See Morissette v. United States, 342 U.S. 246, 256 (1952); Holdridge v. United States, 282 F.2d 302, 310 (8th Cir. 1960); People ex rel. Price v. Sheffield Farms Co., 225 N.Y. 25, 32-33, 121 N.E. 474, 477 (1918) (Cardozo, J.); Commonwealth v. Koczwara, 397 Pa. 575, 255 A.2d 825 (1959). But see United States v. Balint, 258 U.S. 250 (1922), discussed in note 57 supra.

67. 401 U.S. 601 (1971). In Freed, the Court upheld the Firearm Registration Act, 26 U.S.C. $\$ \S 5801-72(1970)$, and found that the Act did not require the government to prove that the defendant knew that the weapon was unregistered. There was no mention in the Court's opinion of the penalties to be imposed for a violation of the Act; penalties, however, were sizable: $\$ 10,000$ fine or 10 years in prison, or both. 26 U.S.C. $\$ 5861$ (1970). Defendant's counsel argued that the size of the penalty made the offense one for which mens rea must be proved. Brief for Appellee at 16-26, United States v. Freed, 401 U.S. 601 (1971). However, this argument was implicitly rejected by the Court. The Court reached a similar result in another case involving a regulatory statute imposing severe penalties. United States v. Balint, 258 U.S. 250 (1922) (sale of narcotics conviction sustained without proof of knowledge that drugs were illegal narcotics).

68. 355 U.S. at 230-31; see pp. 1505-06 supra.

69. The Court in Freed did not explicitly base its decision on this distinction; however, it went to some lengths to explain the nature of the exception to the traditional rule that mens rea must be a requirement in criminal statutes. The Court contrasted Morissette v. United States, 342 U.S. 246 (1952), and Lambert v. California, 355 U.S. 225 (1958), cases in which proof of mens rea was required, with United States v. Dotterweich, 320 U.S. 277 (1943), a case which the Court said involved a "regulatory measure in the interest of public safety" and hence did not require proof of mens rea. 401 U.S. at 607-09. The government in Freed had characterized the statute involved as a regulatory scheme, not as a statute which involved conduct which was malum in se. See Jurisdictional Statement of appellant at 9-10, United States v. Freed, 401 U.S. 601 (1971); Brief for Appellant at 25-30. The Court in Freed appears to have accepted this formulation and to have rejected the argument of the appellees that the statute involved conduct which was actually blameworthy. Brief for Appellees at 23-25. 
preted to require proof of mens rea, a court must discern the purpose of the statute from its language and legislative history. ${ }^{70}$ If the statute proscribes an act because of its "blameworthiness" then proof of mens rea will be required; if it proscribes an act for policy reasons, no proof of mens rea is necessary.

The purpose behind the prohibition of investment of dirty money contained in $\S 1962$ (a) is ambiguous. One view is that Congress considered investment of dirty money a blameworthy act because all the activities of organized crime are blameworthy and threaten American society. ${ }^{71}$ Another view is that the prohibition of investment of dirty money was designed as a social policy to prevent corruption of American business and a resultant decrease in productive economic activity. ${ }^{2}$ The scanty and opaque legislative history could be read to support either of these views.

The problem of whether $\S 1962$ (a) requires proof of mens rea can more easily be resolved through the application of two principles of statutory construction. First, social policy crimes are an exception, founded on lack of blameworthiness, to the common law rule that proof of mens rea is a prerequisite to criminal liability; the seeming lack of a mens rea requirement in $\S 1962(a)$ is, therefore, in derogation of common law. ${ }^{73}$ Statutes in derogation of the common law are strictly construed and thus courts will not presume, absent a clear legislative intent, that a particular statute alters the common law. ${ }^{74}$ Second, statutes punishing social policy crimes have traditionally employed mild penalties. ${ }^{75}$ While this factor no longer serves to distinguish mens rea crimes from non-mens rea crimes, it demonstrates a longstanding practice on the part of legislatures to avoid harsh sanctions for social policy crimes. The fact that $\S 1962$ (a) involves severe penalties is some indication that Congress did not conceive of $\S 1962(a)$ as a social policy statute. Furthermore, the

70. It is the usual practice for the Court to look to legislative history in order to discern the purpose of a statute. See Oregon v. Mitchell, 400 U.S. 112 (1971); Turner v. United States, 396 U.S. 398 (1970); Leary v. United States, 395 U.S. 6 (1969); Katzenbach v. Morgan, 384 U.S. 641 (1964); sources cited in note 36 supra.

71. See Pub. L. No. 91-452, \$1, 84 Stat. 941 (Findings 1-3), note 34 supra.

72. See Pub. L. No. 91.452, $\$ 1,84$ Stat. 941 (Finding 4), note 34 supra.

73. See Morissette v. United States, 342 U.S. 246, 254 n.14 (1952); Dennis v. United States, 341 U.S. 494, 500 (1951) (dictum); Commonwealth v. Koczwara, 397 Pa. 575, 577, 155 A.2d 825, 827 (1959); Mueller, On Common Law Mens Rea, 42 MinN. L. Rev. 1043 (1958); sources cited in note 55 supra.

74. See Moragne v. States Marine Lines, Inc., 398 U.S. 375, 381 (1970); Robert C. Herd \& Co. v. Krawill Mach. Corp., 359 U.S. 297, 304-05 (1959); Isbrandtsen Co. v. Johnson, 343 U.S. 779, 783 (1952); Carpel v. Saget Studios, Inc., 326 F. Supp. 1331, 1333 (E.D. Pa. 1971).

75. See sources cited in note 66 supra. 
draconian penalties provided by $\S 1962(a),{ }^{76}$ if imposed for nonblameworthy conduct, may raise Eighth Amendment problems. ${ }^{77}$ Thus, given a desire to avoid constitutional issues and to uphold long-established principles, courts should presume, in the absence of clear legislative intent, that crimes with harsh penalties are not social policy crimes. ${ }^{78}$

The conclusion that $\S 1962$ (a) does deal with blameworthy conduct and therefore must contain some mens rea requirement still leaves unidentified the particular blameworthy conduct the statute proscribes and thus the specific nature of the mens rea requirement. ${ }^{79}$ Two possible explications of the nature of the blameworthy conduct come to mind. The first is that Congress considered investment of dirty money itself a blameworthy act, one which should be punished in its own right. The second is that Congress meant $\$ 1962$ (a) to be the attempt version of $\S 1962(\mathrm{~b}) .{ }^{s 0}$

One reasonable formulation of the nature of the blameworthy conduct proscribed by $\S 1962(\mathrm{a})$, with some support in the legislative history of the section, ${ }^{81}$ is that $\S 1962$ (a) is an "attempt" version of $\$ 1962(b)$. Under this formulation of the nature of the blameworthy conduct proscribed by $\S 1962(a)$, the mens rea requirement would be the specific intent to do that which is proscribed by $\S 1962(\mathrm{~b})$; that is, intent, by a person aware of the source of the

76. See notes 16-17 supra.

77. The Eighth Amendment question is whether the punishment in $\$ 1962(a)$ is "disproportionate" to the crime; since a severe penalty is imposed for conduct which is not itself blameworthy and since similar punishments are imposed regardless of the intent of the actor, a defendant could argue that the punishment is impermissibly arbitrary in relation to the harm caused. See Lambert v. California, 355 U.S. 225, 230-31 (1958) (Frankfurter, J., dissenting); Weems v. United States, 217 U.S. 349 (1910).

78. See United States v. Bass, 404 U.S. 336 (1971); Schneider V. Smith, 390 U.S. 17 (1968); Green v. McElroy, 360 U.S. 474 (1959); H. HART \& A. S.icks, supra note 57, at 1240-41; Common Law Rules, supra note 48, at 263-64.

79. Cf. United States v. Eppinette, 14 Crim. L. Rer. 2093 (4th Cir. Oct. 3, 1973); State v. Avery, 111 Kan. 588, 207 P. 838 (1922).

80. Compare $\$ 1962$ (a), quoted in full in note 13 supra, with $\$ 1962(\mathrm{~b})$, quoted in note 14 supra. Under this view, the act of investment of dirty money if accompanied by the proper intent would be an attempt to acquire a legitimate business through racketeering activity. The wording of a proposed revision of $\$ 1962$ (a) strongly suggests that the revision is an "attempt" statute. See S.1400, $\$ 1861$ (a)(2), 93d Cong., 1st Sess. (1973).

Generally, in order to prove a person guilty of an attempt, the government must show that the person committed some act in an effort to perpetrate the crime (actus reus) and that the person specifically intended to commit the crime (mens rea). The actus-reus and mens rea together create a "dangerous probability" that the proscribcd act will occur, thus justifying criminal sanctions. Swift \& Co. v. United States, 196 U.S. 375, 396 (1905) (Holmes, J.); see Merrit v. Commonwealth, 164 Va. 653, 660-61, 180 S.E. 395, 398-99 (1935); S. Kadish \& M. Paulsen, Criminal Law and Its Processes $368-410$ (2d ed. 1969); Stuart, Mens Rea, Negligence and Attempts, 1968 CrIM. L. Rev. 617.

81. See Senate Report, supra note 4, at 76-77; Senate Hearings, supra note 4, at 107-08. 
money (i.e., racketeering acts), to invest such money in a business to acquire or control that business through racketeering activity. ${ }^{82}$ While this formulation of the mens rea requirement has surface plausibility, and does seem to better justify the particularly severe sanctions of $\$ 1962(\mathrm{a})$, it is inconsistent with the plain meaning of the provision and with the established congressional practice of specifically labeling all "attempt" statutes as such. ${ }^{83}$ If Congress considered investment of dirty money itself a blameworthy act, the mens rea requirement would be this: Intent to invest dirty money in a legitimate business with the knowledge that the money was derived from racketeering activity. Intent to invest, without more, would not be an acceptable mens rea requirement since it would not include all of the elements of the offense. ${ }^{84}$

It is within Congress' power to decide that a particular act is blameworthy. ${ }^{85}$ Congress has often forbidden particular uses of stolen or embezzled property. Various other provisions in the United States Code prohibit owning a gambling business, ${ }^{86}$ transporting stolen or embezzled goods in interstate commerce, ${ }^{87}$ or selling stolen or embezzled goods in interstate commerce. ${ }^{88}$ Investment of the proceeds of such sale of stolen goods or profits of a gambling business might well be considered an extension of the original crime which gave rise to the income invested. Under this view, the blameworthy con-

82. Section 1962(b) proscribes acquisition of a business through racketeering activity. Although the activity described in $\$ 1962(a)$ is not specifically included in the list of offenses used to define the term "racketeering activity," see note 16 supra, it could be considered racketeering activity. Investment in a business by a racketeer could in some circumstances be a form of extortion (e.g., when a racketeer forces a businessman to accept an investment or loan under threat of physical violence); various forms of extortion are included in the list of offenses in note 15 supra. Furthermore, use of the proceeds of prior racketeering activity to take over a business would itself be considered acquiring a business "through racketeering activity," since the ability to control the business, the harmful event, is a product of the money obtained by racketeering activity; thus there is a takeover "through racketeering activity."

83. The language of $\$ 1962$ (a) does not label it an "attempt" statute, thus violating the "plain meaning" canon of statutory construction, see note 93 infra. Congress in other "attempt" statutes always specifically prohibits "attempts" to do proscribed acts. See, e.g., 18 U.S.C. $\$ 32$ (1970) (attempt to destroy aircraft or aircraft facilities); id. $\$ 33$ (attempt to destroy motor vehicles or motor vehicle facilities); id. $\$ 351$ (c) (attempt to kill or kidnap a member of Congress); id. $\$ 752$ (attempt to escape); id. $\$ 1113$ (attempted murder); id. $\$ 1992$ (attempt to wreck a train); cf. id. $\$ 1962$ (d) (proscribes conspiracy to violate $\$ 1962(a)$ or (b)).

84. See United States v. Freed, 401 U.S. 601, 612, 614 (1971) (Brennan, J., concurring); note 53 supra; cf. United States v. Farquhar, Civil No. 72-1088 (D.C. Cir. Oct. 30, 1973). Apparently this is the mens rea required in a proposed revision of $\$ 1962(\mathrm{a})$. See S.1400, \$ 301(b), 93d Cong., lst Sess. (1973). But see id. \$ 1861(a)(2).

85. There is, of course, some requirement that Congress act reasonably in designating certain behavior as "blameworthy." Cf. Flemming v. Nestor, 363 U.S. 603 (1960); H. HART \& A. SACKs, supra note 57, at 1240-41; see also Packer, supra note 56, at 151-52. 86. 18 U.S.C. $\$ 1955$ (1970).

87. Id. $\$ \$ 659,1708,2314$.

88. Id. $\$ 659,1708,2315$. 
duct proscribed by the statute would be the original crimes-racketeering acts-and investment would be considered a particularly dangerous use of stolen or embezzled property, or the proceeds of that property, obtained by those crimes. This view of $\$ 1962$ (a) accords with the plain meaning of the language used in the statute, ${ }^{80}$ and it is certainly permissible for Congress to increase the penalty for investment of stolen or embezzled property over that for mere possession of stolen goods. ${ }^{90}$ In conclusion, then, courts should find the mens rea of $\S 1962$ (a) to be investment with the knowledge that the money used was derived from racketeering activity.

\section{III}

The evidentiary problems which the government will face when it brings an indictment under $\$ 1962$ (a) are perhaps the most crippling, from the government's point of view, of all the flaws contained in the statute. Section 1962(a) requires for a conviction proof of at least four elements: ${ }^{21}$ ( 1 ) that the defendant committed at least two acts of racketeering or aided and abetted the commission of at least two acts; 92 (2) that the money invested was derived from that racketeering activity; 93 (3) that the money so derived was invested in a legitimate business; and (4) that the defendant invested dirty money with knowledge that the funds were derived from racketeering activity. ${ }^{94}$ That the defendant committed two racketeering acts and invested in a legitimate business might well be amenable to "direct" proof, ${ }^{95}$ though experience suggests that proving even one racketeering act is difficult. Proof of two might be an insurmountable ob-

89. Courts generally interpret a statute according to the plain meaning of its language. See Banks v. Chicago Grain Trimmers Ass'n, 390 U.S. 459 (1968); Com: missioner v. Brown, 380 U.S. 563 (1965); Bouie v. City of Columbia, 378 U.S. 347 (1961). On its face, $\S 1962$ (a) proscribes only the investment of dirty money and nothing else. It follows that the proper mens rea is intent to invest dirty money, the specific act forbidden.

90. See notes 16-17 supra.

91. The government might also have to prove that the investor was a member of a criminal syndicate. See pp. 1498.99 supra. The fact of membership in a criminal syndicate will not be provable by inference. Cf. Masiello v. Norton, 364 F. Supp. 1133 (D. Conn. 1973); see also Sibron v. New York, 392 U.S. 41 (1968).

92. This element involves the question of who are proper defendants under \$ 1962(a). See p. 1495 supra.

93. It should be noted that the government must prove that the funds invested were derived from the racketeering activity proved. It would not be sufficient simply to demonstrate that the source of income of the funds was unknown: $\$ 1962$ (a) specifically states that the money invested must have been derived from the racketeering acts. See note 12 supra.

94. See pp. 1508-10 supra.

95. "Direct" proof, in this context, means identification testimony or material evidence which establishes a fact. See note 98 infra. 
stacle. ${ }^{96}$ The two remaining elements are not likely to be amenable to direct proof; ${ }^{97}$ hence, the government will seek to rely on inferences. ${ }^{08}$

The present test for determining whether an inference ${ }^{99}$ can be constitutionally employed in a criminal prosecution is that there be a rational ${ }^{100}$ connection between the proved facts and the presumed

96. See SENATE RETORT, supra note 4, at 44; Senate Hearings, supra note 4, at 109, 111-12; 1970 U.S. CODE CoNG. \&. ADM. NEws 1076-84; sources cited in note 4 supra.

97. Because money is fungible, it would be virtually impossible for the government to prove with "direct" proof that the money invested was the money derived from the racketeering acts, particularly given the length of time likely to elapse between the various transactions (the two racketeering acts and the investment) and the fact that money changes hands frequently. Indeed, current evidence suggests that underworld figures keep detailed records indicating that most of their income is derived from legitimate sources. See $\mathrm{D}$. CRESSEY, supra note 1, at 69-70, 77, 291-92; SENATE REPORT, supra note 4, at 44, 76; Senate Hearings, supra note 4, at 111 , 176 .

Proof of criminal intent will require proof that the defendant knew that the money was dirty; the same proof problems just mentioned would thus have to be faced. Such proof would probably be directly available only through the defendant's own testimony in court or through wiretaps. Information about racketeers is virtually impossible to obtain from insiders, whose voluntary testimony might endanger their lives. See Senate Report, supra note 4, at 199. (Title V of OCCA-70, 84 Stat. 933, see note 6 supra, was designed to deal with this problem.) Granting the defendant immunity to preserve his Fifth Amendment rights would be futile, since the likely result would be that the defendant could not be prosecuted. See Note, Standards for Exclusion in Immunily Cases After Kastigar and Zicarelli, 82 YALE L.J. 171, 175-81 (1972).

98. To some extent, most proof involves inferences. Because the trier of fact was not present when the crime was committed, he must, in effect, infer what actually happened from the testimony of the various witnesses. See United States v. Becker, 62 F.2d 1007 (2d Cir. 1933) (L. Hand, J.). What is commonly meant by the term "inference," in the context of the law of evidence, is, however, evidence which asks the trier of fact to reach a certain conclusion by reasoning only from certain sub. sidiary facts, themselves testified to, which taken together could suggest that an event occurred. This distinction between "direct" or "testimonial" evidence and inferential evidence is developed in the case law holding that an inference may not be supported by another inference. See United States v. Ross, 92 U.S. 281 (1875); Westland Oil Co. v. Firestone Tire \& Rubber Co., 143 F.2d 326, 330 (8th Cir. 1944); Kearny v. Thomas, 225 N.C. 156, 33 S.E.2d 871 (1945); Richter v. Seawell, 183 Va. 379, 32 S.E.2d 62 (1944). For a more theoretical explanation of the distinction between direct and inferential proof, see Commonwealth v. Harman, 4 Pa. 269, 271 (1846) (Gibson, C.J.); 1 J. WiGMORE, EVIDENCE $\$ \S 25,26$, at 398-406 (3d ed. 1940).

99. Courts typically speak of judicial inference and statutory presumption as virtually synonymous terms and apply the same tests in determining their validity in criminal prosecutions. See Barnes v. United States, 412 U.S. 837 (1973); McAbee v. United States, 434 F.2d 361 (9th Cir. 1970); United States v. Ripso, 338 F. Supp. 662 (E.D. Pa. 1972); People v. Kirkpatrick, 32 N.Y.2d I7, 295 N.E.2d 753, 343 N.Y.S.2d 70, appeal dismissed, 94 S. Ct. 283 (1973).

100. The word "rational" is a term of art. In order for an inference to be found "rational," the desired conclusion must be more likely than not to follow from the proven facts as tested by common experience. See Leary v. United States, 395 U.S. 6 (1969). Generally courts will adduce evidence on their own motion, if necessary, to determine whether a particular inference is true more likely than not.

The "more likely than not" standard may, however, be insufficient in this context. Common law principles require that every element of a criminal offense must be proved beyond a reasonable doubt. See United States v. Adams, 293 F. Supp. 776, 783.85 (D.D.C. 1968); C. MCCormick, Evidence 674, 681-82 (1954); Model Penal Code, $\$ 1.12$ (Prop. Official Draft, 1962). If this standard were applied to inferences, it would scem to indicate that the "more likely than not" standard is not stringent enough for a criminal case. In Leary v. United States, supra, the Court left open the question of which standard applies to inferences in criminal cases "more likely than not" or 
facts. The presumed fact must more likely than not flow from the facts proved, or it must be something which is obvious from common experience. ${ }^{101}$

An inference that the money invested was derived from the proven racketeering acts would meet this standard only if the government could show that during the period in question the investor did not have a sufficiently large income from legitimate sources to cover the investment. ${ }^{102}$ In other words, it would be more likely than not that the racketeer invested money derived from racketeering acts if it could be shown that the racketeer did not have enough legitimate income to insure that the investment could have been made with altogether "clean" money. The problem with supporting such an inference is that it is unlikely that the government would be sufficiently informed about the investor's finances to establish how much of his income was legitimate and how much came from unlawful sources. ${ }^{103}$

Faced with such lack of knowledge, the government would have to establish that some of the racketeer's supposedly legitimate income (i.e., an amount large enough to prove that the racketeer did not have sufficient "clean" money to cover the alleged investment) was not in fact legitimate; the government would have to prove that it was actually "laundered" income-the proceeds of an original investment of dirty money. ${ }^{104}$ It is unlikely that the government could prove,

"beyond a reasonable doubt"). 395 U.S. at 36 n.64. See Barnes v. United States, 412 U.S. 837, $841-46$ (1973); Turner v United States, 396 U.S. 398, 405 (1970). In Leary, the Court added the words "substantial assurance" to the test of rationality. 395 U.S. at 36. That is, the Court said that a presumption could not be applied in a criminal prosecution unless it could be said, "with substantial assurance," that the presumed fact was more likely than not to follow from the proven fact. This additional requirement implies that the Court was not satisfied with the "more likely than not" test. At least one court has opted for the "beyond a reasonable doubt" standard. United States v. Adams, 293 F. Supp. 776 (D.D.C. 1968).

101. See Turner v. United States, 396 U.S. 398 (1970); Leary v. United States, 395 U.S. 6 (1969); United States v. Gainey, 380 U.S. 63 (1965); Tot v. United States, 319 U.S. 463 (1943); McAbee v. United States, 434 F.2d 361 (9th Cir. 1970); United States v. Ripso, 338 F. Supp. 662 (E.D. Pa. 1972); Commonwealth v. Owens, 441 Pa. 318, 271 A.2d 518 (1970).

102. It is certainly far from clear that the mere fact that an investor possessed some dirty money would support an inference that the dirty money was used for in. vestment under the "beyond a reasonable doubt" standard. It is at least as likely that the investor used the dirty money for consumption and invested clean money. Only if he did not have sufficient clean funds to cover the investment would the inference satisfy the "more likely than not" standard.

103. It is likely that the financial records of a well-advised racketeer would attribute all of his income to legitimate sources. See note 87 supra.

104. The government would have to show that the investment could not have been made but for the use of some laundered money. Misreporting the actual source of income would be a violation of 26 U.S.C. $\$ 7206$ (1970), and thus, if the government prior to the passage of $\$ 1962$ (a) could prove that a racketeer had laundered dirty money, it could prosecute the racketeer under income tax laws. 
directly or inferentially, that a particular sum of money was "laundered." 105 Proof that some of a person's income was derived from racketeering would not support an inference that it is more likely than not that all or any part of the person's income was actually derived, directly or indirectly, from racketeering. ${ }^{106}$

Proving intent promises to be equally troublesome. The government ordinarily establishes intent or knowledge in a criminal prosecution by requesting that the jury be permitted to infer intent or knowledge from the circumstances surrounding the crime. ${ }^{107}$ If the

105. See note 97 supra.

106. If the government could prove that a racketeer had $\$ 100$ in income, had probably derived $\$ 10$ from racketcering, and had made a $\$ 30$ investment (but could not prove that the money invested was actually dirty), it would still not be rational to infer that the investment was made with dirty money. It is not more likely than not that the $\$ 10$ derived from racketeering was used in the $\$ 30$ investment. There are many things besides investment for which the $\$ 10$ could have been used.

An inference designed to show that all of a racketeer's income was derived from racketecring or that the legitimate sources of income were actually illegal, since an original investment of dirty money had tainted all subsequent income, could take the form of the community property mixing funds presumption. This presumption is a device used to simplify proof in civil actions concerning tax matters and property settlement questions. See W. Burby, Handeook of The LaW of Real Property 236-66 (3d ed. 1965). Before the mixing funds presumption could be used in a criminal prosecution, it would be necessary to determine whether it would meet the standard for constitutional inferences.

The mixing funds presumption provides that if separate funds are commingled with community funds, so that the separate funds cannot be traced, the commingled funds are community property. See Rose v. Rose, 82 Idaho 395, 353 P.2d 1089 (1960); Munn v. Munn, 63 Wash. 2d 349, 387 P.2d 547 (1963); see generally W. BuRuY, supra, at 236-66.

If this presumption were applied to a racketeer, it would mean that unless he could prove that he had disposed of all of the money that he had derived from racketeering without mixing it with other funds (that is, that he had used all of the dirty money for consumption needs), all of his money would be considered tainted.

This presumption is not rational. In terms of United States v. Leary, 395 U.S. 6 (1969), the connection between the proved fact-that some dirty money was mixed with clcan money-and the presumption-that all of the money was therefore dirtyis purely arbitrary. The presumption is permissible in civil cases for efficiency reasons; a higher standard, however, is applied in criminal prosecutions. See, e.g., North American Van Lines, Inc. v. United States, 249 F.2d 693 (6th Cir. 1957).

The mixing funds presumption might also place an unconstitutional burden of proof on the defendant. It would require the defendant to prove that he had not used any of the money derived from racketeering for investment, thus placing the burden of tracing on him, rather than requiring the government to prove such a use. The government could argue, without proof, that the defendant was guilty. In effect, the defendant would have to prove he was innocent of the charge. See United States v. Gaincy, 380 U.S. 63, 78-79 (1965) (Douglas, J., dissenting on other grounds); MoDEL Penal Code, $\$ 1.13$, Commentary (Tent. Draft No. 4, 1955), at 108-18.

In tax cases the government uses tracing rules like "first in, first out" to establish that the taxpayer actually had more income than he claimed to have had. These rules cannot establish anything more specific than the taxpayer's actual net worth; that is, they cannot be used to reveal the specific sources of his income. See Duke, supra note 10 , at $8-34$. Thus, tracing rules would not aid the government in a prosecution under $\$ 1962(\mathrm{a})$. The government would still have to prove that some money was derived from racketeering.

107. See, e.g., United States v. Melton, Civil No. 72-1357 (D.C. Cir. Sept. 26, 1973) at 5.6; United States v. Floyd, 477 F.2d 217 (9th Cir. 1973); United States v. Solomon, 422 F.2d 1110 (7th Cir.); cert. denied sub nom. Sommers v. United States, 399 U.S. 911 (1970). This way of establishing intent also raises the question of whether the standard of proof is "more likely than not" or "beyond a reasonable doubt." See note 100 supra. 
government were able to prove that the investor did not have sufficient "legitimate" income to cover the investment or that the investor's seemingly "legitimate" income was actually "dirty," then it might be rational, under the Tot-Leary ${ }^{108}$ requirements, for a court to permit a jury to infer that the investor knew that the money was dirty, hence establishing the investor's intent to invest dirty money. However, without such proof, a jury could not permissibly infer knowledge of investment of dirty money from the defendant's mere possession of some dirty money, since it would be just as possible that the racketeer believed the money he was investing was legitimate.

Further, even if the government could prove enough to permit the inference of knowledge of the source of the money to go to the jury, that would still not, by itself, establish intent to acquire control of the business. Investment alone does not establish such intent. Hence, inferring knowledge that funds invested were proceeds of racketeering activity merely from proof that the defendant committed two prior racketeering acts, derived money from those acts, and at some later time invested some money whose source could not be determined would not be rational. 109

Thus it would appear that the government will be facing some of the same kinds of proof problems under $\S 1962$ (a) that it faces generally in attempting to control organized crime. ${ }^{110}$ The fact that no indictments have been brought under $\S 1962(a)^{111}$ and that, in contrast, indictments against organized crime generally have increased ${ }^{112}$ may indicate that the proof problems under $\S 1962(a)$ are especially intractable. None of the present bills pending in Congress ${ }^{113}$ dealing with the recodification and reform of Title 18 have addressed the proof problems inherent in $\$ 1962(a)$.

\section{IV}

If the language ambiguities of $\S 1962$ (a) were remedied, and if it were made clear what the purpose of the statute is, hence clarifying the mens rea problem, $\S 1962$ (a) would then at least be a comprehensible statute. However, such clarification would not address the

108. Leary v. United States, 395 U.S. 6 (1969); Tot v. United States, 319 U.S. 463 (1943). 109. Such inference would be purely arbitrary. Only if some specific evidence was introduced which tended to establish intent would the inference be permissible. See pp. 1511-12 supra.

110. See sources cited in notes 4,95 supra.

111. See note 19 supra.

112. Assistant Attorney General Petersen reported a sixty percent increase in indictments of organized crime figures in 1972. See 10 BNA CrIM. L. REP. 2467 (1972).

113. See note 21 supra. 
major flaw of the statute: The statute adds virtually no new weapon to secure convictions against racketeers. The elements of the offense which are not amenable to direct proof cannot be proved by way of inferences, because no constitutional inference could be designed. Such a serious flaw must call the wisdom of the statute into question. When Congress is called upon to adopt the revised Federal Criminal Code, it should carefully scrutinize $\S 1962$ (a) and the approach to the threat of organized crime it contains. Congress should recognize that the problem of control of organized crime will not be solved by the creation of esoteric new crimes and draconian punishments. The problem with the enforcement of criminal laws against organized crime is and always has been a problem of evidence-gathering. 'It is to this problem that Congress should turn its attention. 